\title{
IIII 291997
}

\section{UST}

\section{Low-Temperature Growth and Orientational Control in $\mathrm{RuO}_{2}$ Thin Films by Metal-Organic Chemical Vapor Deposition*}

\author{
G.-R. Bai, A. Wang, C.M. Foster, and J. Vetrone \\ Materials Science Division \\ Argonne National Laboratory \\ 9700 S. Cass Avenue, Argonne, IL 60439 \\ J. Patel and X. Wu \\ Physics Department \\ Northern Illinois University \\ DeKalb, IL 60115
}

\section{August 1996}

\begin{abstract}
The submitted manuscript has been created by the University of Chicago as Operator of Argon:ne National Laboratory ("Argonne") under Contract No. W-31-109-ENG-38 with the U.S. Department of Energy. The U.S. Government retains for itself, and others acting on its behalf, a paid-up, nonexclusive, irrevocable worldwide license in said article to reproduce, prepare derivative works, distribute copies to the public, and perform publicly and display publicly, by or on behalf of the Government.
\end{abstract}

Manuscript to be submitted to Applied Physics Letters.

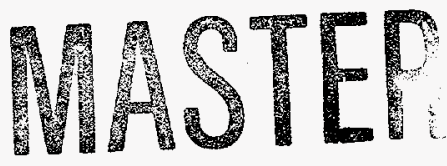

*Work supported by the U.S. Department of Energy, Basic Energy Sciences-Materials Sciences, DISTRISUTION OF THS VOCUNENT IS UNUMITED 


\section{DISCLAMMER}

Portions of this document may be illegible in electronic image products. Images are produced from the best available original document. 


\title{
Low-Temperature Growth and Orientational Control in $\mathrm{RuO}_{2}$ Thin Films by Metal-Organic Chemical Vapor Deposition
}

\author{
G.-R. Bai, A. Wang, C. M. Foster and J. Vetrone \\ Materials Science Division, \\ Argonne National Laboratory, \\ 9700 South Cass Avenue, \\ Argonne, IL 60439.
}

J. Patel and X. Wu

Physics Department

Northern Illinois University

DeKalb, IL 60115

\begin{abstract}
For growth temperatures in the range of $275^{\circ} \mathrm{C}$ to $425^{\circ} \mathrm{C}$, highly conductive $\mathrm{RuO}_{2}$ thin films with either (110)- or (101)-textured orientations have been grown by metal-organic chemical vapor deposition (MOCVD) on both $\mathrm{SiO}_{2} / \mathrm{Si}(001)$ and $\mathrm{Pt} / \mathrm{Ti} / \mathrm{SiO}_{2} / \mathrm{Si}(001)$ substrates. Both the growth temperature and growth rate were used to control the type and degree of orientational texture of the $\mathrm{RuO}_{2}$ films. In the upper part of this growth temperature range $\left(-350^{\circ} \mathrm{C}\right)$ and at a low growth rate ( $<30 \AA / \mathrm{min}$.), the $\mathrm{RuO}_{2}$ films favored a (110)-textured. In contrast, at the lower part of this growth temperature range $\left(-300^{\circ} \mathrm{C}\right)$ and at a high growth rate $\left(>30 \AA \mathrm{min}\right.$.), the $\mathrm{RuO}_{2}$ films favored a (101)-textured. In contrast, a higher growth temperatures $\left(>425^{\circ} \mathrm{C}\right)$ always produced randomly-oriented polycrystalline films. For either of these low-temperature growth processes, the films produced were crack-free, well-adhered to the substrates, and had smooth, specular suffaces. Atomic force microscopy showed that the films had a dense microstructure with an average grain size of 50-80 nm and a rms. surface roughness of $\sim 3-10 \mathrm{~nm}$. Four-probe electrical transport measurements showed that the films were highly conductive with resistivities

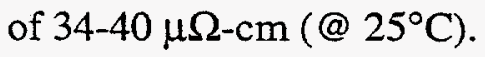

\section{DISCLAIMER}

This report was prepared as an account of work sponsored by an agency of the United States Government. Neither the United States Government nor any agency thereof, nor any of their employees, makes any warranty, express or implied, or assumes any legal liability or responsibility for the accuracy, completeness, or usefulness of any information, apparatus, product, or process disclosed, or represents that its use would not infringe privately owned rights. Reference herein to any specific commercial product, process, or service by trade name, trademark, manufacturer, or otherwise does not necessarily constitute or imply its endorsement, recommendation, or favoring by the United States Government or any agency thereof. The views and opinions of authors expressed herein do not necessarily state or reflect those of the United States Government or any agency thereof. 
There has been considerable interest in the deposition of highly conductive metallic oxide thin films as metallization material for Very-Large-Scale-Integrated (VLSI) circuits. Ruthenium oxide, $\mathrm{RuO}_{2}$, has been studied due to is thermal stability, low resistivity, and superior diffusion barrier properties [1-5]. Various applications of $\mathrm{RuO}_{2}$ thin films in integrated circuits have been explored [2,6]. For example, the use of $\mathrm{RuO}_{2}$ thin films as precision resistors in integrated circuits (IC's) has been extensively investigated [7-9]. Recently, $\mathrm{RuO}_{2}$ thin films have been studied as electrode layer for integrated ferroelectric or high- $\varepsilon$ (dielectric constant) thin-film storagenode capacitors [10-16] in high-density dynamic-random-access (DRAM) and non-volatile (NVRAM) memory applications. By using $\mathrm{RuO}_{2}$ thin-film electrodes as opposed to conventional $\mathrm{Pt}$ electrodes, the polarization fatigue resistance of $\mathrm{Pb}\left(\mathrm{Zr}_{\mathrm{x}} \mathrm{Ti}_{1-\mathrm{x}}\right) \mathrm{O}_{3}$ (PZT)-based thin film capacitors can be dramatically improved $[11,17,18]$, particularly for compositions near the morphotropic boundary [19].

A variety of thin film deposition techniques, including RF-magnetron $[3,13,16]$ and DCsputtering [2,7-9], $R F$ reactive sputtering [4,5,12,14,15,17], pulsed laser deposition (PLD) [20], and metal-organic chemical vapor deposition (MOCVD) [1,21,22], have been used to fabricate $\mathrm{RuO}_{2}$ thin films. Among these methods, MOCVD offers the significant advantages for the highdensity IC fabrication: well-developed tool clustering and design, excellent composition and thickness uniformity, high deposition rates, superior step coverage and via infiltration capability, and scalability to large wafer sizes. However, in previous reports of the deposition $\mathrm{RuO}_{2}$ thin films using MOCVD [1,21], the growth temperatures were high $\left(>550^{\circ} \mathrm{C}\right)$ resulting in films with a random polycrystalline structure. These films exhibited a high electrical resistivity $(60-90 \mu \Omega-$ $\left.\mathrm{cm} @ 25^{\circ} \mathrm{C}\right)$ when compared to that of bulk $\mathrm{RuO}_{2}\left(35.2 \pm 0.5 \mu \Omega-\mathrm{cm} @ 25^{\circ} \mathrm{C}\right.$ [23]). $\mathrm{Pb}\left(\mathrm{Zr}_{0.82} \mathrm{Ti}_{0.18}\right) \mathrm{O}_{3}$ thin films deposited on these $\mathrm{RuO}_{2}$ electrodes showed inferior polarization hysterisis [24] as compared to PZT films grown on Pt electrodes [10-11,19], even after postgrowth high-temperature annealing. Recently, lower-temperature MOCVD processing $\left(\sim 350^{\circ} \mathrm{C}\right)$ of $\mathrm{RuO}_{2}$ thin films has been reported [22]. These films were randomly-oriented polycrystals on $\mathrm{SiO}_{2} / \mathrm{Si}(001)$ substrates and also showed higher-than-bulk resistivity $\left(60 \mu \Omega\right.$-cm @ $\left.25^{\circ} \mathrm{C}\right)$.

For many electronic or optical device applications, $\mathrm{RuO}_{2}$ thin films that are structurally highly-textured are more attractive than randomly-oriented polycrystalline films for three reasons. First, such films typically have a dense columnar-grained microstructure. Since grain boundary scattering is a dominant electron-scattering mechanism in $\mathrm{RuO}_{2}$ [25], $\mathrm{RuO}_{2}$ thin films with an ordered microstructure should show a lower resistivity. Second, a highly-textured $\mathrm{RuO}_{2}$ layer can better serve as a structural template for subsequent growth of multi-layer structures, particularly for amorphous substrate surfaces such as $\mathrm{SiO}_{2} / \mathrm{Si}(001)$. Third, if the preferred orientation of the $\mathrm{RuO}_{2}$ layer can be controlled, the orientation of subsequent layers can be controlled. In this letter, we present low-temperature growth processes for highly-textured $\mathrm{RuO}_{2}$ thin films 
on $\mathrm{SiO}_{2} / \mathrm{Si}(001)$ and $\mathrm{Pt}(111) / \mathrm{Ti} / \mathrm{SiO}_{2} / \mathrm{Si}(001)$ substrates using MOCVD. We describe the structure and electrical conductivity of the deposited $\mathrm{RuO}_{2}$ films with an emphasis on the correlation of the growth parameters, particularly the growth temperature and growth rate, to the film structure.

The deposition of $\mathrm{RuO}_{2}$ thin film was carried out in a low-pressure, horizontal, cold-wall, quartz reactor with a resistive substrate heater. $\mathrm{Si}(001)$ with a native $\mathrm{SiO}_{2}$ layer and $\mathrm{Pt}(111) / \mathrm{Ti} / \mathrm{SiO}_{2} / \mathrm{Si}(001)$ wafers were chosen as substrates. Prior to the $\mathrm{RuO}_{2}$ deposition, the substrates were cleaned using a sequence of acetone, methyl alcohol, and de-ionized water. Tris(2,2,6,6-tetramethyl-3,5-heptanedionato) ruthenium, $\mathrm{Ru}(\mathrm{TMHD})_{3}$, was used as the ruthenium precursor. The organometallic precursor vapors were introduced into the reactor via a high purity nitrogen carrier gas. Film growth rate was controlled by adjusting the carrier gas flow and the ruthenium source temperature. Pure oxygen was used as the oxidant and introduced into the reactor through a separate line. The details of the reactor design and deposition procedures have been previously reported [26]. The optimized growth conditions for obtaining textured $\mathrm{RuO}_{2}$ films on $\mathrm{SiO}_{2} / \mathrm{Si}(001)$ and $\mathrm{Pt}(111) / \mathrm{Ti} / \mathrm{SiO}_{2} / \mathrm{Si}(001)$ substrates are shown in Table 1.

TABLE 1. Growth Conditions for $\mathrm{RuO}_{2}$ Thin Films

\begin{tabular}{ll}
\hline \hline Substrate Temperature & $250-600^{\circ} \mathrm{C}$ \\
Reactor Pressure & 4 torr \\
$\mathrm{Ru}(\mathrm{TMHD})_{3}$ Precursor Temperature & $112-118^{\circ} \mathrm{C}$ \\
Flow Rate of $\mathrm{O}_{2}$ Reactant Gas & $120 \mathrm{sccm}$ \\
Flow Rate of $\mathrm{N}_{2}$ Carrier Gas & $20-50 \mathrm{sccm}$ \\
Flow Rate of $\mathrm{N}_{2}$ Background Gas & $50 \mathrm{sccm}$ \\
Film Thickness & $1000-1500 \AA$ \\
Film Growth Rate & $20-40 \AA / \mathrm{min}$. \\
Substrate Materials & $\mathrm{SiO}_{2} / \mathrm{Si}(001), \mathrm{Pt}(111) / \mathrm{Ti} / \mathrm{SiO}_{2} / \mathrm{Si}(001)$ \\
\hline \hline
\end{tabular}

The dependence of structure and crystallinity of the deposited films on the growth parameters, such as growth temperatures and growth rates, were investigated using $\mathrm{x}$-ray diffraction. Film thickness was measured from a Dektak 3030 surface profilometer. Surface roughness and morphology of $\mathrm{RuO}_{2}$ films were analyzed using scanning electron microscopy (SEM) and atomic force microscopy (AFM). Four-point probe measurements were used to characterize the conductivity of $\mathrm{RuO}_{2}$ films. 
First, while keeping all other growth conditions constant, we investigated the effect of growth temperature on $\mathrm{RuO}_{2}$ thin films deposited on $\mathrm{SiO}_{2} / \mathrm{Si}(001)$ substrates. For $\mathrm{RuO}_{2}$ films grown above $500^{\circ} \mathrm{C}$, the film surface appeared very rough, sometimes containing cracks, and occasionally peeling away from the substrate. The resistivity of these films was above $1000 \mu \Omega$ $\mathrm{cm}$. For $\mathrm{RuO}_{2}$ films grown below $\sim 250^{\circ} \mathrm{C}$, the films were smooth, amorphous and also highly resistive. For $\mathrm{RuO}_{2}$ films grown between $250^{\circ} \mathrm{C}$ and $450^{\circ} \mathrm{C}$, the films were smooth and highly conductive; however, the structure of the films was very sensitive to the growth temperature. When the growth temperature was higher than $425^{\circ} \mathrm{C}$, the films were always polycrystalline with random orientation. However, as the growth temperature decreased, the structure of the films tended to texture. Furthermore, the texture of the $\mathrm{RuO}_{2}$ films could be controlled depending on the growth temperature. In Fig. 1 , we show the $\mathrm{x}$-ray $\theta-2 \theta$ scans for $\mathrm{RuO}_{2}$ films processed at three different growth temperatures in this range. The film grown at $425^{\circ} \mathrm{C}$ (upper) is polycrystalline with no preferred orientation. In contrast, the film grown at $350^{\circ} \mathrm{C}$ (middle) is highly (110)-textured and the film grown at $300^{\circ} \mathrm{C}$ (bottom) is highly (101)-textured.

Second, we also studied the effect of growth rate on the degree of structural texture of the deposited films. In Fig. 2, we show $\mathrm{x}$-ray $\theta-2 \theta$ scans for $\mathrm{RuO}_{2}$ films grown at two different growth rates at growth temperatures of $350^{\circ} \mathrm{C}$ (a) and $300^{\circ} \mathrm{C} \mathrm{(b).} \mathrm{For} \mathrm{RuO}_{2}$ films grown at $350^{\circ} \mathrm{C}$ (Fig. 2a), a growth rate of greater than $30 \AA / \mathrm{min}$. reduced the degree of (110) texture (upper), as indicated by the appearance of $\mathrm{RuO}_{2}$ (101), (200) and (211) peaks in the x-ray pattern. In contrast, a growth rate of less than $30 \AA / \mathrm{min}$. resulted in a high degree of (110) texture (lower). For $\mathrm{RuO}_{2}$ films grown at $300^{\circ} \mathrm{C}$ (Fig. $2 \mathrm{~b}$ ), a growth rate of less than $30 \AA / \mathrm{min}$. reduced the degree of (101) texture (lower), as indicated by the appearance of $\mathrm{RuO}_{2}$ (110), (200) and (211) peaks in the $\mathrm{x}$-ray pattern. In contrast, a growth rate of greater than $30 \AA / \mathrm{min}$. resulted in a high degree of (101) texture (upper).

Based on above observations, we draw the following conclusions. First, as the growth temperature decreases, the $\mathrm{RuO}_{2}$ thin films on $\mathrm{SiO}_{2} / \mathrm{Si}(001)$ tend to structurally texture. Second, for a fixed growth rate in this low-growth-temperature regime, increased growth temperature favors (110)-textured films; whereas, decreased growth temperature favors (101)-textured films. Third, for fixed growth temperature, lower growth rates favor (110)-textured films, and higher growth rates favor (101)-textured films.

The structural texturing of thin films on amorphous surfaces has been treated extensively [27]. In this case, since the native $\mathrm{SiO}_{2}$ layer of the $\mathrm{Si}(001)$ surface is amorphous, it is expected that the film nucleation process on this surface should be isotropic, irrespective of growth temperature and growth rate. However, since the structure of $\mathrm{RuO}_{2}$ is tetragonal, the growth of the nucleation centers once they are formed will be anisotropic, with film growth in specific crystallographic direction favored over others. When the growth temperature is high (i. e., $>400^{\circ} \mathrm{C}$ 
for $\mathrm{RuO}_{2}$ ), adatoms have sufficient thermal energy to diffuse and migrate on the $\mathrm{SiO}_{2} / \mathrm{Si}(001)$ surface so that the growth rate of nucleation crystallites of various orientation are relatively equivalent. Consequently, the resultant structure of the film is a randomly-oriented polycrystal.

In contrast, for low growth temperatures (i. e., $<400^{\circ} \mathrm{C}$ for $\mathrm{RuO}_{2}$ ), adatoms are less mobile which results in the suppression of crystallite growth in some direction. Consequently, the film become textured. We have previously reported similar low-temperature texturing in MOCVD-processed $\mathrm{PbTiO}_{3}$ thin films grown on $\mathrm{SiO}_{2} / \mathrm{Si}(001)$ [28]. Furthermore, changes in the arrival rate of reactants at substrate surface changes the degree of supersaturation of the vapor phase. This can also strongly affect the texturing of the film changing the nucleation density on the substrate surface. This either increases or decreases the required diffusion distance for adatoms to reach nucleation centers, and consequently affects the structural texture of the film [27]. These process have been previously discussed theoretically [29].

It has been shown that by using a composite electrode structures of $\mathrm{RuO}_{2} / \mathrm{Pt}$, PZT-based capacitors do not exhibit the high-leakage-current densities typical of $\mathrm{RuO}_{2}$ electrodes neither the substantial cyclic fatigue associated with Pt electrodes [18]. Consequently, we have also studied the textured growth of $\mathrm{RuO}_{2}$ films on $\mathrm{Pt}(111) / \mathrm{Ti} / \mathrm{SiO}_{2} / \mathrm{Si}(001)$ substrates. As shown in Fig. 3, the growth-temperature (a) and growth-rate (b) dependence of the structural texture of $\mathrm{RuO}_{2}$ films deposited on $\mathrm{Pt}(111) / \mathrm{Ti} / \mathrm{SiO}_{2} / \mathrm{Si}(001)$ substrates is similar as that observed for $\mathrm{SiO}_{2} /$ $\mathrm{Si}(001)$ substrates. Fig. $3 a$ shows the $\mathrm{x}$-ray $\theta-2 \theta$ scan results for $\mathrm{RuO}_{2}$ films grown at $350^{\circ} \mathrm{C}$ (upper) and $300^{\circ} \mathrm{C}$ (lower), respectively. The structure of $\mathrm{RuO}_{2}$ films grown at $350^{\circ} \mathrm{C}$ is (110) textured while that of films grown at $300^{\circ} \mathrm{C}$ is (101) textured. Fig. $3 \mathrm{~b}$ shows the $\mathrm{x}$-ray $\theta-2 \theta$ scan results for $\mathrm{RuO}_{2}$ films grown at $300^{\circ} \mathrm{C}$ on $\mathrm{Pt}(111) / \mathrm{Ti} / \mathrm{SiO}_{2} / \mathrm{Si}(001)$ but at different growth rates. For a growth rate of less than $30 \AA / \mathrm{min}$. reduced the degree of (101) texture (lower), as indicated by the appearance of $\mathrm{RuO}_{2}(110),(210)$ and (211) peaks in the $\mathrm{x}$-ray pattern. While a growth rate of greater than $30 \AA / \mathrm{min}$. resulted in a high degree of (101) texture (upper).

All the $\mathrm{RuO}_{2}$ films grown in the temperature range of $275-425^{\circ} \mathrm{C}$ are crack-free, uniform and specular morphology, adhering well to both $\mathrm{SiO}_{2} / \mathrm{Si}(001)$ and $\mathrm{Pt}(111) / \mathrm{Ti} / \mathrm{SiO}_{2} / \mathrm{Si}(001)$ substrates. In Fig. 4, we show AFM micrographs of the surface of $1500 \AA$-thick $\mathrm{RuO}_{2}$ films grown on $\mathrm{SiO}_{2} / \mathrm{Si}(001)$ at $350^{\circ} \mathrm{C}$ with (110)-texture (a) and at $300^{\circ} \mathrm{C}$ with (101)-texture (b). From the images, we can see that both types of films had dense microstructures with an average grain size of 500-800 $\AA$. We determined that the films exhibited root mean squared roughness over an area of $25 \mu \mathrm{m}^{2}$ of $10.1 \pm 0.2 \mathrm{~nm}$ for (110) textured films (a) and $3.5 \pm 0.2 \mathrm{~nm}$ for (101) textured films (b). Using the four-point probe method, we found that all the $\mathrm{RuO}_{2}$ films grown in the temperature range of $275-425^{\circ} \mathrm{C}$ had typical resistivities of $34-40 \mu \Omega-\mathrm{cm} @ 25^{\circ} \mathrm{C}$. These resistivities are very close to that of bulk $\mathrm{RuO}_{2}$ [23], lower than that reported previously for MOCVD-grown $\mathrm{RuO} 2$ films $[1,21,22]$, and similar to that reported for epitaxial $\mathrm{RuO}_{2}$ film grown by PLD on 
$\mathrm{Si}(001)$ using yttria-stabilized zirconia buffer layers [20]. We have also previously shown that MOCVD-processed $\mathrm{Pb}\left(\mathrm{Zr}_{0.5} \mathrm{Ti}_{0.5}\right) \mathrm{O}_{3}$ thin films deposited on the (110)-textured $\mathrm{RuO}_{2}$ electrodes exhibited excellent ferroelectric hysteresis and fatiuge characteristics [30].

In summary, at temperatures as low as $275^{\circ} \mathrm{C}$, highly conductive $\mathrm{RuO}_{2}$ thin films with either (110)- and (101)-textured orientations have been grown by MOCVD on both $\mathrm{SiO}_{2} / \mathrm{Si}(001)$ and $\mathrm{Pt} / \mathrm{Ti} / \mathrm{SiO}_{2} / \mathrm{Si}(001)$ substrates. The structural texture of the $\mathrm{RuO}_{2}$ films was controlled by both growth temperature and growth rate. Higher growth temperatures and lower growth rates favor growth of (110)-textured films, while lower growth temperatures and faster growth rates favor growth of (101)-textured films. All the $\mathrm{RuO}_{2}$ films grown in the temperature range of 275$425^{\circ} \mathrm{C}$ are crack-free, uniform and specular morphology, adhering well to both $\mathrm{SiO}_{2} / \mathrm{Si}(001)$ and $\mathrm{Pt}(111) / \mathrm{Ti} / \mathrm{SiO}_{2} / \mathrm{Si}(001)$ substrates with typical resistivities of 35-40 $\mu \Omega-\mathrm{cm} @ 25^{\circ} \mathrm{C}$.

This work was supported by the United States Department of Energy, Basic Energy Sciences-Materials Sciences, under Contract No. W-31-109-ENG-38.

\section{REFERENCES}

1. M.L. Green, M.E. Gross, L.E. Papa, K.J. Schnoes, and D. Brasen, J. Electronchem. Soc. 132, 2677 (1985).

2. L. Krusin-Elbaum, M. Wittmer, and D.S. Yee, Appl. Phys. Lett. 50, 1879 (1987).

3. E. Kolawa, F. C. T. So, E. T.-S. Pan, and M.-A. Nicolet, Appl. Phys. Lett. 50, 854 (1987).

4. A. Belkind, Z. Orban, J. L. Vossen, and J. A. Woollam, Thin Solid Films 50, 242 (1992).

5. F. C. T. So, E. Kolawa, X.-A. Zhao, E. T.-S. Pan, and M.-A. Nicolet, J. Vac. Sci. Technol. B5, 1784 (1987).

6. M. Wittmer, J. Vac. Sci. Technol. A2, 273 (1984).

7. Q. X. Jia, Z. Q. Shi, K. L. Jiao, W. A. Arderson, and F. M. Collins, Thin Solid Films 196, 29 (1991).

8. Q. X. Jia, K. L. Jiao, W. A. Arderson, and F. M. Collins, Mater. Sci. Eng. B18, 220 (1993).

9. Q. X. Jia, H. J. Lee, E. Ma, W. A. Arderson, and F. M. Collins, J. Mater. Res. 10, 1523 (1995).

10. I. K. Yoo and S. B. Desu, Phys. Status Solidi A133, 565 (1992).

11. H. N. Al-Shareef, A. I. Kingon, X. Chen, K. R. Bellur, and O. Auciello, J. Mater. Res. 9, 2968 (1994).

12. K. Maiwa, N. Ichinose, and K. Okazaki, Jpn. J. Appl. Phys. 33, (9B) 5223, (1994). 
13. K. Yoshikawa, T. Kimura, H. Noshiro, S. Otani, M. Yamada, and Y. Furumura, Jpn. J. Appl. Phys. 33, (6B) L867, (1994).

14. J.-G. Lee, S.-K. Min, and S. H. Choh, Jpn. J. Appl. Phys. 33, (12B) 7080, (1994).

15. L. A. Bursill, I. M. Reaney, D. P. Vijay and S. B. Desu, J. Appl. Phys. 75, 1521 (1994).

16. K. Takemura, T. Sakuma, Y. Miyasaka, Appl. Phys. Lett. 64, 2968 (1994); K. Takemura,

S. Yamamichi, P.-Y. Lesaicherre, K. Tokashiki, H. Miyamoto, H Ono, Y. Miyaska, and M. Yoshida, Jpn. J. Appl. Phys. 34, (9B) 5224, (1995).

17. S. D. Bernstein, T. Y. Wong, Y. Kisler, and R. W. Tustison, J. Mater. Res. 8, 12 (1993).

18. H. N. Al-Shareef, K. R. Bellur, A. I. Kingon, and O. Auciello, Appl. Phys. Lett. 66, 239 (1995).

19. H. N. Al-Shareef, B. A. Tuttle, W. L. Warren, T. J. Headley, D. Dimos, J. A. Voigt, and R. D. Nasby, J. Appl. Phys. 79, 1013 (1996).

20. Q. X. Jia, S. G. Song, X. D. Wu, J. H. Cho, S. R. Foltyn, A. T. Findikoglu, and J. L. Smith, Appl. Phys. Lett. 68, 1069 (1996).

21. J. Si and S. B. Desu, J. mater. Res. 8, 2644 (1993).

22. T. Takagi, I. Oizuki, I. Kobayashi, and M. Okada, Jpn. J. Appl. Phys. 34, (8A) 4104, (1995).

23. The Oxide Handbook, edited by G. V. Samsonov, translated by C. N. Turton and T. I. Turton (Plenum Press, New York, 1973), p. 203; W. D. Ryden, A. W. Lawson, C. C. Sartain, Phys Rev. B1, 1494 (1970).

24. C. H. Peng and S. B. Desu, Appl. Phys. Lett. 61, 16 (1992).

25. S. Y. Mar, J. S. Liang, C. Y. Sun, and Y. S. Huang, Thin Solid Films 238, 158 (1994).

26. G.-R. Bai, H. L. M. Chang, C. M. Foster, Z. Shen, and D. J. Lam, J. Mater. Res. 9, 156 (1994).

27. For a review, see Oriented Crystallization on Amorphous Substrates, by E. I. Givargizov (Plenum Press, New York, 1991) or E. Bauer, "Growth of oriented films on amouphous surfâces", in Single-Crystal Films edited by M. H. Francombe and H. Sato, (Macmillan, New York, 1964) pp. 43-67.

28. B. M. Yen, D. Liu, G.-R. Bai and H. Chen, J. Appl. Phys. 76, 4805 (1994).

29. S. Lichter and J. Chen, Phys.Rev. Lett. 56, 1396 (1996); R. Messier and J. E. Yehoda, J. Appl. Phys. 58, 3739 (1985).

30. C. M. Foster, G.-R. Bai, A. Wang, J. Vetrone, Y. Huang and R. Jammy, Integrated Ferroelectrics (in press). 
Figure Captions:

Figure 1: $\quad \mathrm{X}$-ray diffraction patterns of $\mathrm{RuO}_{2}$ films on $\mathrm{SiO}_{2} / \mathrm{Si}(001)$ showing changes in the type and degree of structural texture for films processed at different growth temperatures: $425^{\circ} \mathrm{C}$ (upper), $350^{\circ} \mathrm{C}$ (middle) and $300^{\circ} \mathrm{C}$ (bottom).

Figure 2: $\quad \mathrm{X}$-ray diffraction patterns of $\mathrm{RuO}_{2}$ films on $\mathrm{SiO}_{2} / \mathrm{Si}(001)$ showing the effects of growth rate on the degree of structural texture for films processed at two growth temperatures: (a) $350^{\circ} \mathrm{C}$ and (b) $300^{\circ} \mathrm{C}$. The upper curves are for high growth rates (>30 $\AA / \mathrm{min}$.) and the lower curves are for low growth rates (<30 $\mathrm{A} / \mathrm{min}$.).

Figure 3: $\quad \mathrm{X}$-ray diffraction patterns of $\mathrm{RuO}_{2}$ films on $\mathrm{Pt}(111) / \mathrm{Ti} / \mathrm{SiO}_{2} / \mathrm{Si}(001)$ substrates showing the growth-temperature (a) and growth-rate (b) dependence of the structural texture. Shown two growth temperatures: $350^{\circ} \mathrm{C}$ (a, upper) and $300^{\circ} \mathrm{C}$ (a, lower) and two growth rates for films grown at $300^{\circ} \mathrm{C}:<30 \AA / \mathrm{min}$. (b, lower), and $>30 \AA / \min$. (b, upper).

Figure 4: AFM micrographs of the surface of $1500 \AA$-thick $\mathrm{RuO}_{2}$ films grown on $\mathrm{SiO}_{2} / \mathrm{Si}(001)$ at $350^{\circ} \mathrm{C}$ with (110)-texture (a) and at $300^{\circ} \mathrm{C}$ with (101)-texture (b). 


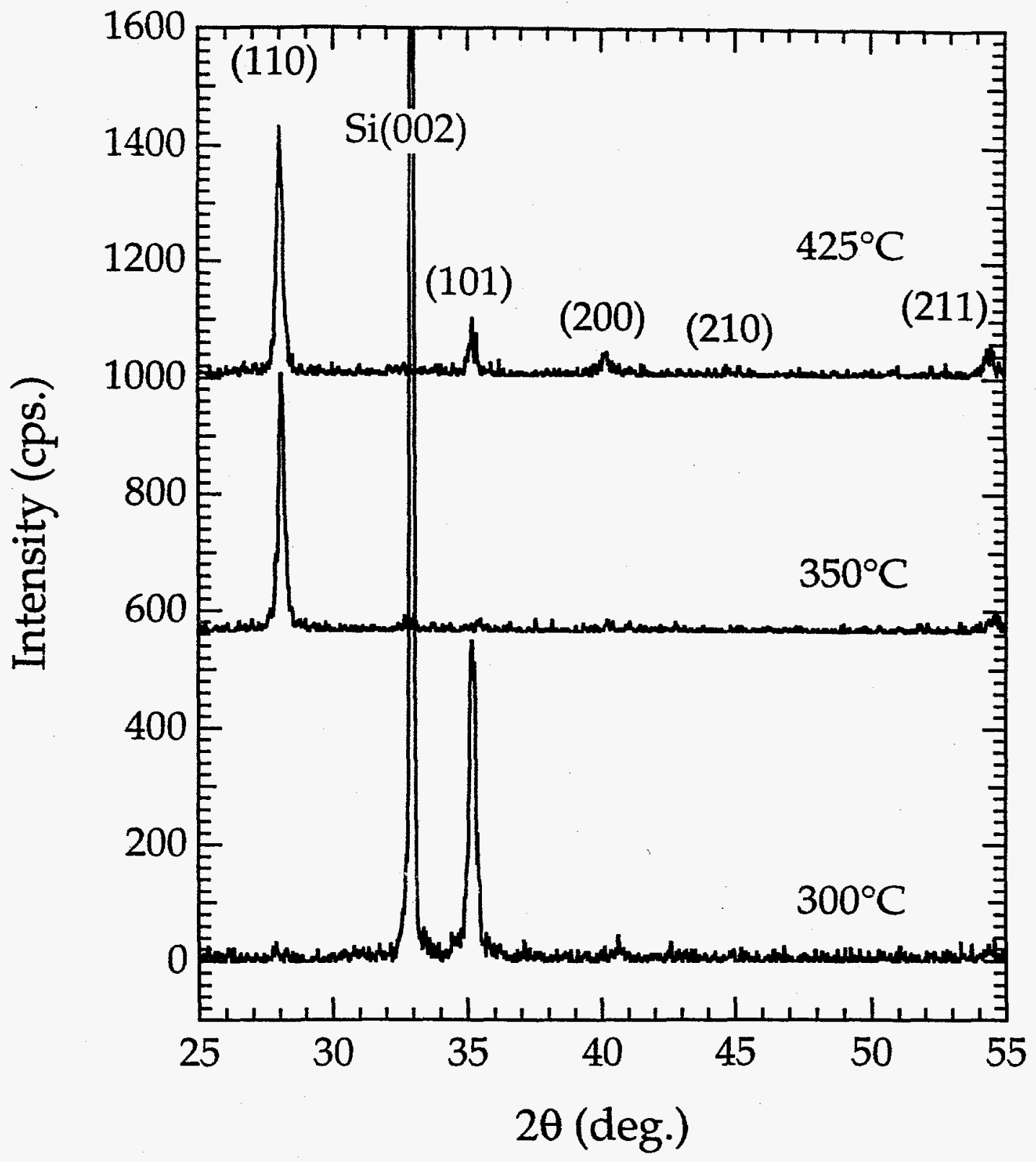

FIG. 1 


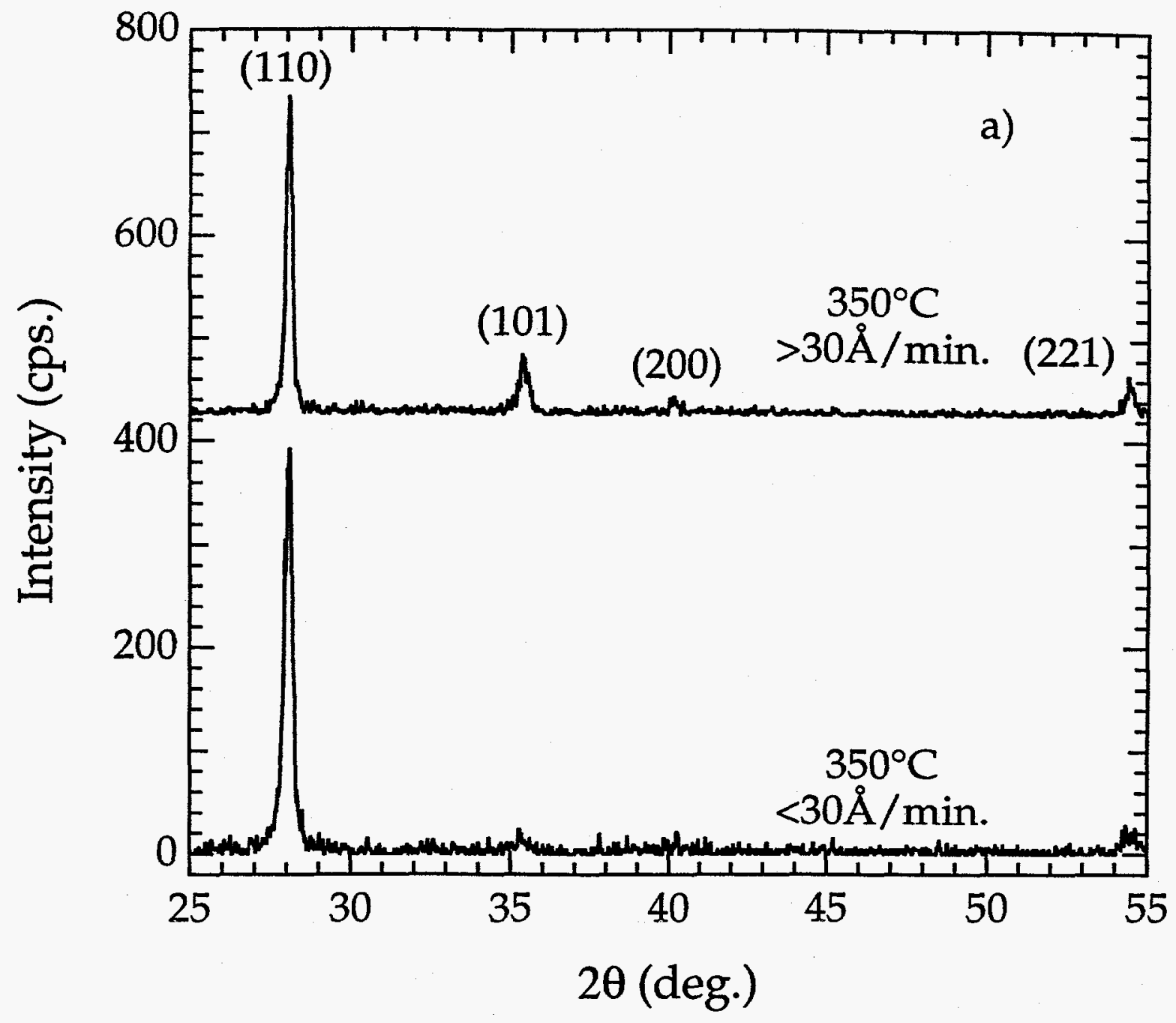

FIG. $2 A$ 


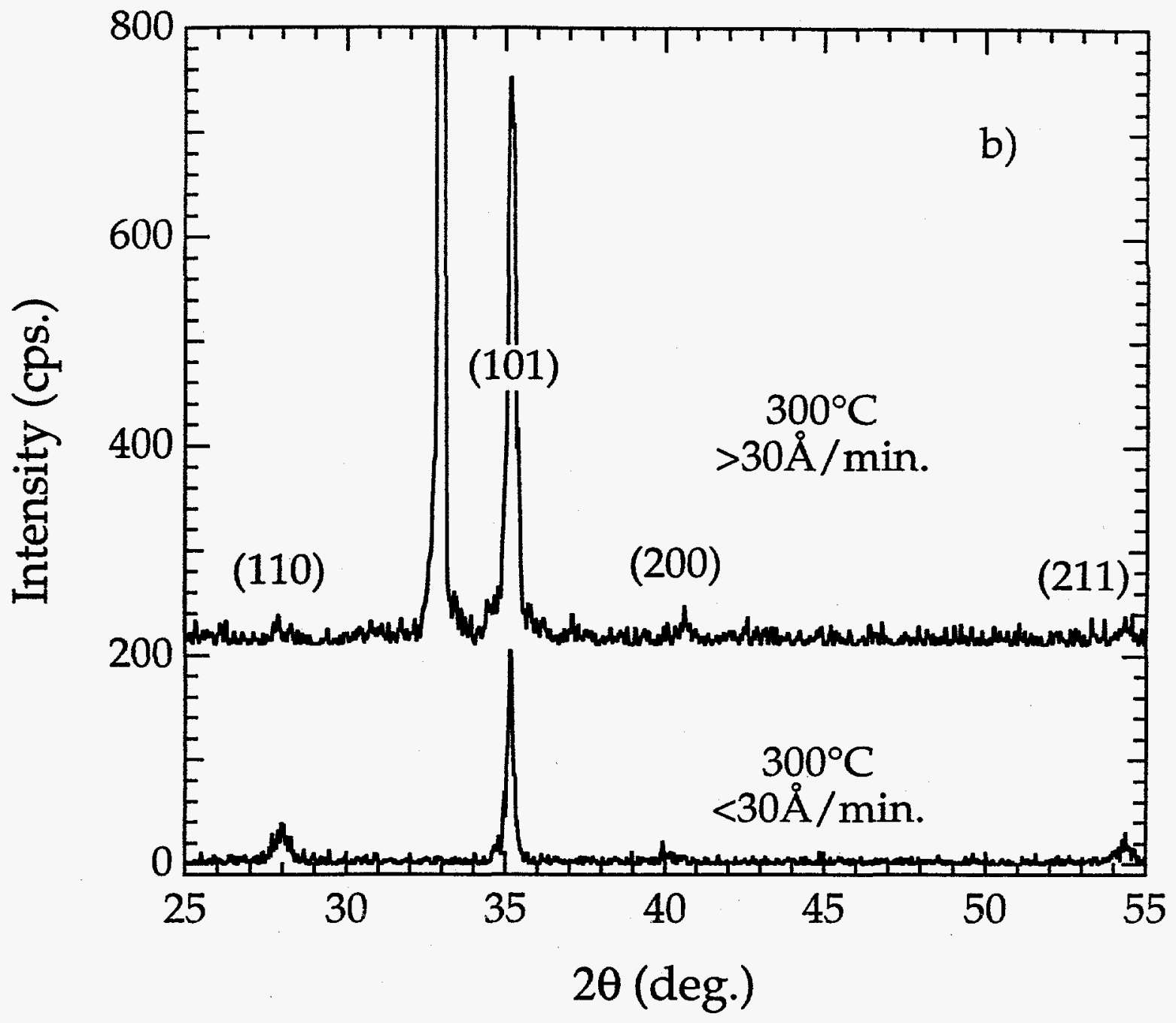

$F I G .2 B$ 


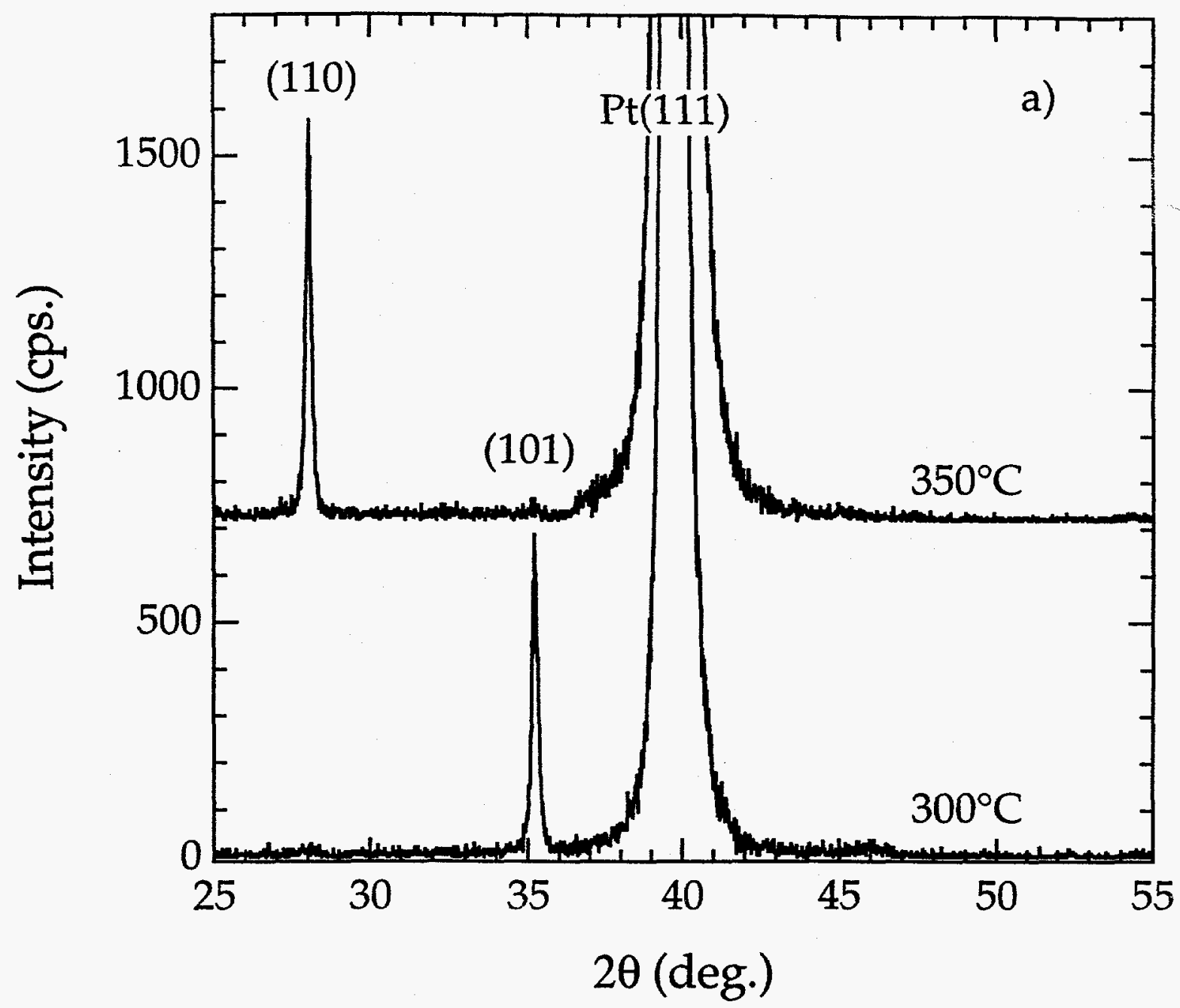

$F I G .3 A$ 


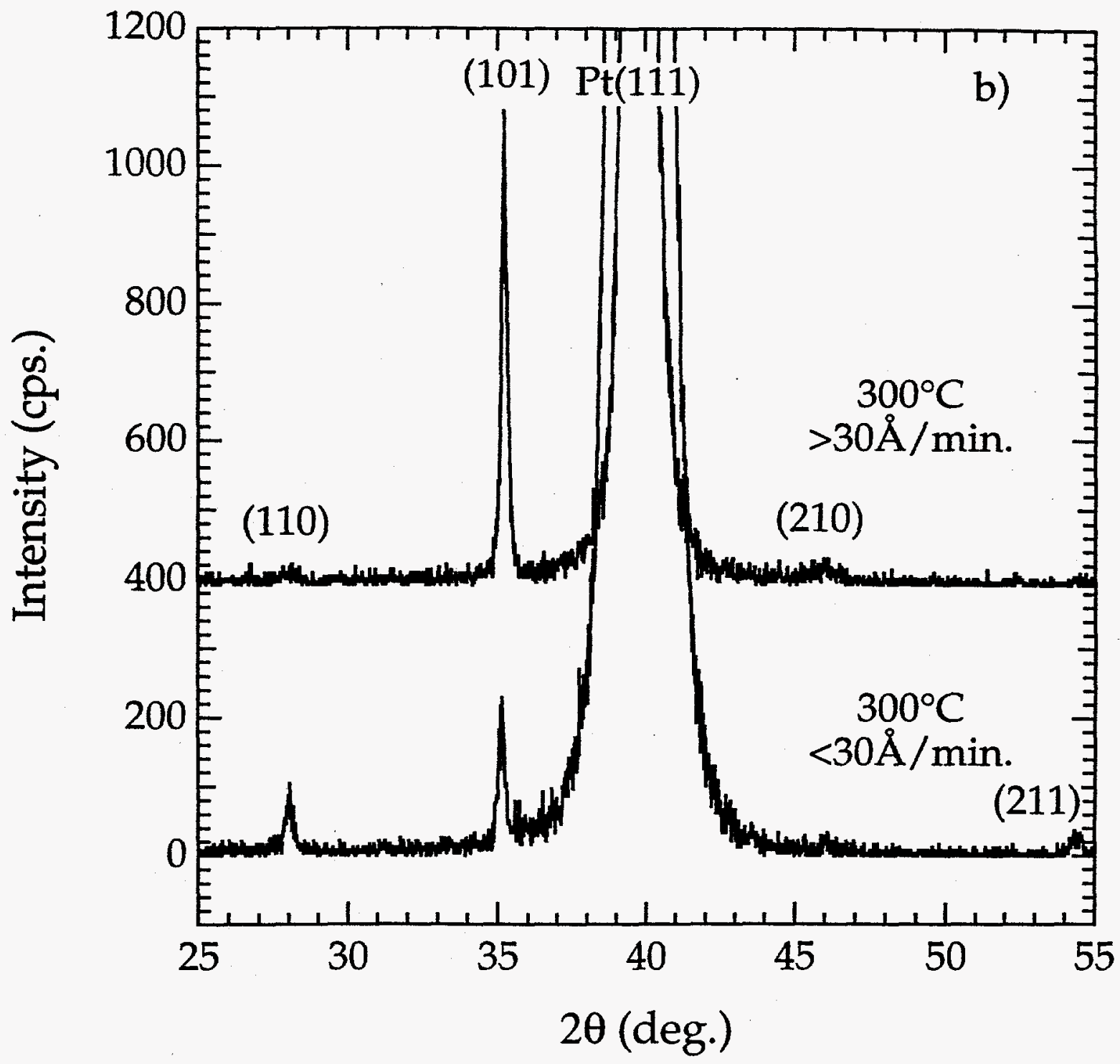

$F I G-3 B$ 


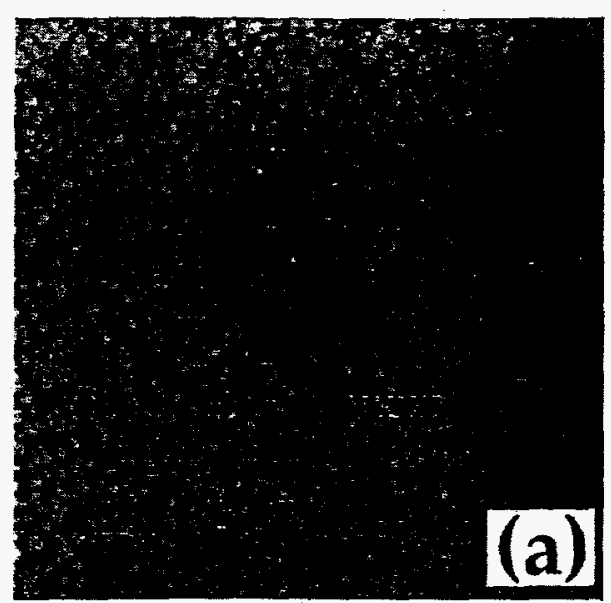

75 nm
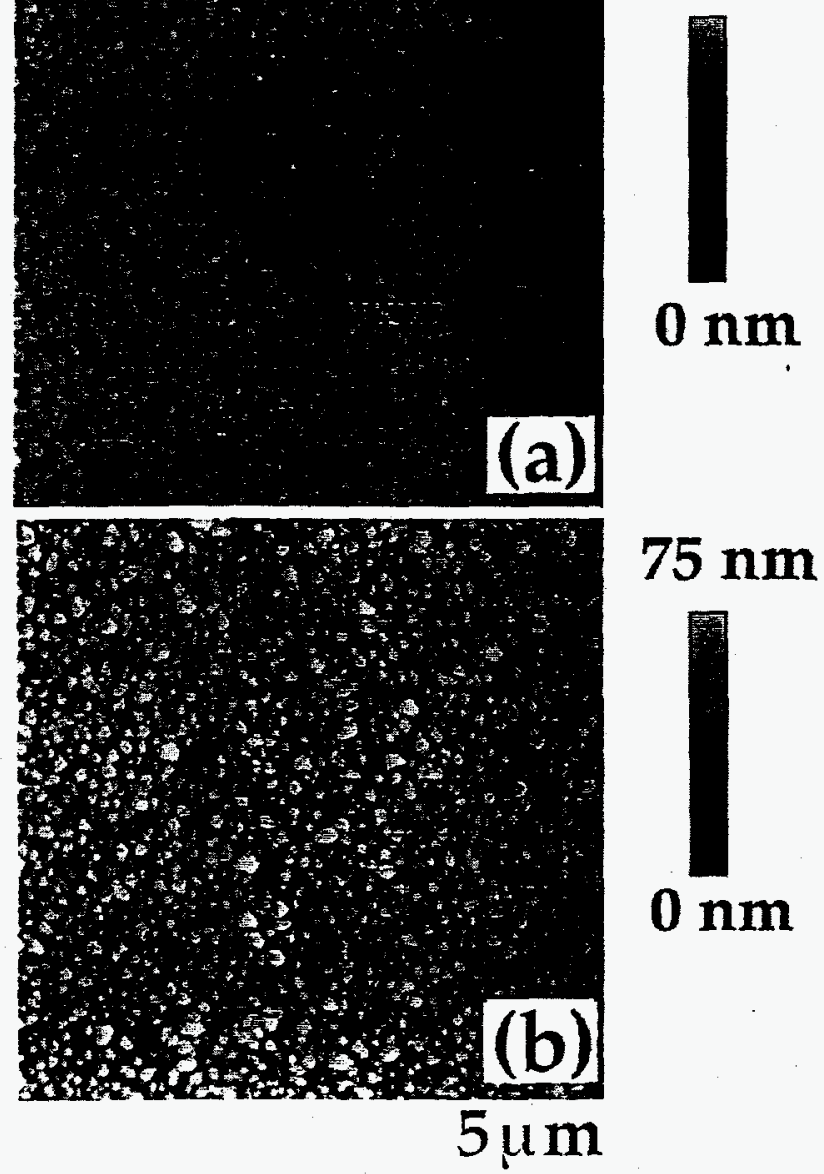

$75 \mathrm{~nm}$
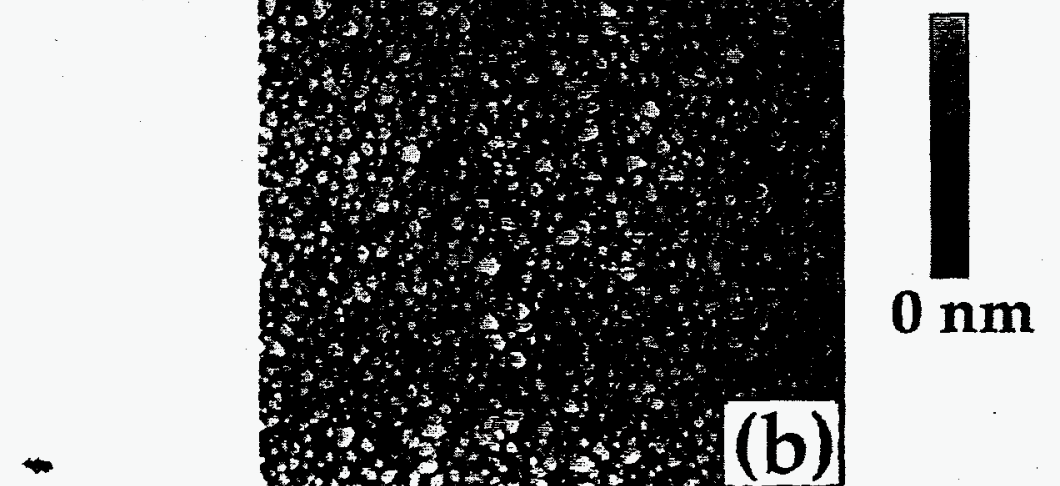